investigators. Some of the results of the work appear from time to time in the Journal of Entomology and Zoology, which is published quarterly by the college.

There are of course great gaps in the whole plan. Only here and there can a little be done at a time, but it is believed that by encouraging classes and individuals to collect data and specimens, and, when well trained, to record observations of a more difficult nature, we have an opportunity to do a great work which is unique and can not help but benefit all who partake in the effort. Whatever may be the value of the facts obtained and tested, whatever the value of the discovery of new species or new adaptations, there is, I believe, the value of method for the beginning student or the more advanced one. It will not matter what study he pursues after leaving college for the university; an awakened interest in things out of doors, an increased accuracy of observation should result. It seems to me too that the thought of contributing something to science, no matter how small a fact, ought also to be a stimulus in the future as it has been in the past.

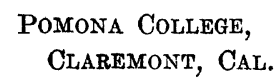

\section{WINSLOW UPTON}

Winslow Upton, professor of astronomy and director of the Ladd observatory at Brown University, died of pneumonia, at Providence, on January 8 , in the sixty-first year of his age. His forbears were of north England origin but early in the seventeenth century the founder of the New England family emigrated to Massachusetts. Professor Upton was born on October 12, 1853, and was the fourth son of James Upton, a prominent merchant of Salem, Mass., and a liberal contributor to Brown University. Entering Brown in 1871 he was graduated as valedictorian of the class of 1875 . He had attained to almost equal excellence in the pursuit of studies in ancient classics and in science, but he felt that his forte was rather in the line of scientific investigation. So he turned to the University of Cincinnati for graduate work in astronomy and was there awarded the degree of A.M. in 1877. His alma mater conferred on him the honorary degree of Sc.D. in 1906.

He was assistant in the astronomical observatory at Harvard, 1877-79; assistant engineer in the U. S. Lake Survey at Detroit, 1879-80; computer in the U. S. naval observatory at Washington, 1880-81; computer and assistant professor in the U. S. Signal office, 1881-84.

In 1884 he was appointed professor of astronomy at Brown University and since 1891 he has been both professor of astronomy and director of the Ladd observatory (the gift of the late Governor H. W. Ladd) which was built under his supervision. The facilities of the observatory have been used chiefly to aid in the instruction of the university, in the maintenance of a local time service, and in regular meteorological observations in cooperation with the U. S. Weather Bureau.

Professor Upton has been connected with a number of important scientific parties. He was a member of the U. S. astronomical expeditions to observe the total eclipse at Denver, Colorado, in 1878, and at the Caroline Islands in the South Pacific, in 1883. He also observed the solar eclipse of 1887 in Russia, that of 1889 in California, of 1900 in North Carolina, and during a sabbatical year, 189697 , he was attached to the southern station of the observatory of Harvard College, at Arequipa, Peru.

Professor Upton's publications, for the most part in the department of meteorology, include the following:

1. "The Solar Eclipse of 1878," a lecture before the Essex Institute (Bulletin of the Essex Institute, Vol. 11. 1879; reprinted, pp. 19).

2. "Photometric Observations Made Principally with the Equatorial Telescope of Fifteen Inches Aperture During the Years 1877-79"; by E. C. Pickering, C. Searle and W. Upton (Harvard Astr. Obs. Ann., Vol. 11, 1879, pp. 317).

3. "Information Relative to the Construction and Maintenance of Time-balls" (Wash- 
ington, 1881, pp. $31+3$ pls., U. S. War Dept. Professional papers of the Signal office, No. 5).

4. "Lectures on Practical Astronomy," 1882 (Report of the Chief Signal Officer, Washington, 1882, pp. 104-120).

5. "On the Methods Adopted in the Computation of Barometric Reduction Constants" (Report of the Chief Signal Officer, Washington, 1882, appendix 61, pp. 826-846, Washington, 1883).

6. "The Use of the Spectroscope in Meteorological Observations" (U. S. signal service notes, No. IV., pp. $7+3$ pls., Washington, 1883).

7. "Report of Observations Made on the Expedition to Caroline Islands to Observe the Total Eclipse of May 6, 1883" (reprinted from Memoirs of the National Academy of Sciences, Vol. 2, Washington, 1884, pp. $64+$ 7 pls.).

8. "Distribution of Rainfall in New England February 10-14, 1886, from Observations reported to the New England Meteorological Society" (reprinted from ScIEnce of March 19, 1886, Providence, 1886, pp. 8).

9. "An Investigation of Cyclonic Phenomena in New England" (1887).

10. "Meteorological Observations During the Solar Eclipse August 19, 1887, at Chlamostina, Russia" (reprinted from the American Meteorological Journal, Ann Arbor, 1888, pp. 25).

11. "The Storm of March 11-14, 1888 " (reprinted from American Meteorological Journal, May, 1888, pp. 19).

12. "Characteristics of New England Climate" (Harvard Astr. Obs. Ann., Vol. 21, 1890, pp. 265-273).

13. "Meteorologial and Other Observations Made in Connection with the Total Solar Eclipse of January 1, 1889, at Willows, California," by W. Upton and A. L. Rotch (Harvard Astr. Obs. Ann., Vol. 29, 1892, pp. $34+$ 2 pls.).

14. "Star Atlas, Containing Stars Visible to the Naked Eye and Clusters, Nebulæ, and Double Stars Visible in Small Telescopes ... and an Explanatory Text" (Boston, Ginn and Co., 1896, pp. iv + 34 .
15. "Geographical Position of Arequipa Station" (Harvard Astr. Obs. Ann., Vol. 48, 1903, pp. $52+1$ pl.).

$\mathrm{He}$ was also the contributor of numerous short articles to the Astronomische Nachrichten since 1877, to Zeitschrift für Meteorologie, Siderial Messenger, Popular Astronomy, Science, American Meteorological Journal, Astronomical Journal and other scientific publications. For over twenty years he wrote monthly letters on astronomical topics for the Providence Journal and was editor of the astronomical part of the Providence Journal Almanac 1894-1910.

Professor Upton was a fellow of the American Association for the Advancement of Science, a member of the Deutsche Meteorologische Gesellschaft, of the Phi Beta Kappa, Sigma Xi Societies and of the Delta Upsilon fraternity. He married, in 1882, Miss Cornelia Augusta Babcock, of Lebanon Springs, $\mathrm{N}$. Y., and their two daughters are graduates of Smith College.

At Brown University Professor Upton was secretary of the faculty 1884-91, Dean 1900 1901 , one of the committee on organization of the movement to increase the university endowment 1910-11; and, for more than a score years, a member of important administrative committees. $\mathrm{He}$ was also an active church worker, endowed with rare simplicity, genuineness, and warmth of Christian faith, and, at different times, glee-club and choir leader, and organist. His musical talents' (so often the possession of astronomers and mathematicians) were inherited from his father; the George P. Upton who has given us many a pleasing volume on musical topics is a distant relative.

Professor Upton was possessed of unusual scientific ability, coupled with brilliancy and rare clarity of thought and power of exposition of intricate subjects. Too much, it seemed to some, did the university demand of his time and strength to deal with administrative problems, when he might so easily have multiplied his contributions to science. That extensive projects in this direction were contemplated are indicated by manuscripts left behind. He had a good deal of personal 
magnetism, a joyous appreciation of refined humor, and was constantly in demand as a lecturer. In the class-room he displayed exceptional power to arouse enthusiasm. He was tactful and of judicial temper, a man inspired with the highest ideals in the conduct of life and possessed of unfailing patience, of great tenderness of heart and kindliness of spirit. He was beloved alike by colleagues and students.

Only a week ago, our friend was in the classroom. Because of the tragic swiftness of his passing-for just the other day he seemed to us but in the prime of bodily and mental vigor-a pregnant hush of introspection pervades the academic community. This afternoon his body was borne to his native city.

"Warte nur, balde
Ruhest du auch.",

R. C. Arohibald

BRown UNIVERSITY,

January 10, 1914

\section{SCIENTIFIC NOTES AND NEWS}

THE fourth annual award of the Willard Gibbs Medal, founded by Mr. William A. Converse, will be made by the Chicago Section of the American Chemical Society to Dr. Ira Remsen, of Johns Hopkins University. The previous recipients of this medal are Professor Svante Arrhenius, Professor Theodore W. Richards and Dr. Leo H. Baekeland. The formal presentation will be made to Dr. Remsen at the May meeting of the Chicago Section of the American Chemical Society. Dr. Remsen has formally signified his acceptance of this award. The jury of award which selected Dr. Remsen comprised Mr. William Brady, Mr. G. Thurnauer, Dr. E. C. Franklin, Dr. W. R. Whitney, Professor J. H. Long, Professor J. Stieglitz, Professor Alexander Smith, Professor W. A. Noyes, Mr. E. B. Bragg; Mr. S. T. Mather, Professor W. H. Walker and Professor T. W. Richards.

AT the recent meeting of the American Physical Society at Atlanta, in connection with the American Association for the Advancement of Science, the following officers were elected for 1914: President, Ernest Mer- ritt, of Cornell University; Vice-president, Karl E. Guthe, of the University of Michigan; Secretary, A. D. Cole, of the Ohio State University; Treasurer, J. S. Ames, of the Johns Hopkins University; Members of Council, G. K. Burgess, of the Bureau of Standards, and D. C. Miller, of the Case School of Science; Managing Editor of Physical Review, F. Bedell, of Cornell; Editorial Board, A. G. Webster, of Clark University, C. E. Mendenhall, of the University of Wisconsin, and H. A. Bumstead, of Yale University. The next two meetings of the Physical Society will be at Columbia University, New York, on February 28, and at the Bureau of Standards, Washington, on April 24 and 25.

Dr. August Weismann, professor of zoology at Freiburg, celebrated on January 17 his eightieth birthday.

THE Imperial Society of the Friends of Natural History, Anthropology and Ethnology, of Moscow, have elected Professor W. M. Davis to permanent membership.

The Imperial Academy of Sciences of St. Petersburg has elected Sir Edward Thorpe as a corresponding member.

Professor Silvanus P. Thompson has been elected a corresponding member of the Academy of Sciences of Bologna.

Professor Johannes Orth, head of the pathological laboratory at the University of Berlin, has been elected an honorary member of the London Institute of Hygiene.

Dr. JOSEPH T. ROTHROCK, who is now seventy-four years old, has resigned as a member of the Pennsylvania State Forestry Board after serving for twenty years, in order to devote more time to private work.

Octave Chanute medals have been awarded by the Western Society of Engineers for the best three papers presented during the year 1913 as follows: mechanical and electrical engineering, Mr. W. L. Abbott on "The Northwest Station of the Commonwealth Edison Company"; general engineering, Mr. Onward Bates on "Arbitration"; civil engineering, Mr. D. W. Mead on "The Cause of 